\title{
Challenges Encountered by Principals during Implementation of ICT in Public Secondary Schools, Kenya
}

\author{
Laaria Mingaine
}

School of Management, Shanghai University 99 Shangda Road, Shanghai, China Tel: +86-139-1651-0024.

E-mail: mingainesl@yahoo.com

Accepted: April 03, 2013 Published: May 14, 2013

Doi:10.5296/jsr.v4i2.3552 URL: http://dx.doi.org/10.5296/jsr.v4i2.3552

\begin{abstract}
Information Communication Technology (ICT) has contributed greatly to advancement of education in schools globally. However, in Kenyan schools barely use ICT tools to raise teacher productivity, or manage the quality of output, or reduce costs through analyzing expenditures. This is attributed to many challenges facing most schools with regards to implementation of the technology which has resulted to slow rate of adoption and use of ICT, despite its promise and potential in education. This study surveyed some of the challenges principals faced during its implementation.
\end{abstract}

The study adopted a descriptive survey research design. The target population included 350 public secondary school principals in Meru County. One hundred and five (105) respondents which represented $30 \%$ were sampled using stratified and simple random sampling. Questionnaires were used as main instruments for data collection. Validity of the questionnaires was ensured through judgment of experts, while reliability was established through test and re-tests method during pilot study. Ninety $(85.71 \%)$ questionnaires were appropriately filled and return. Data analysis employed both inferential and descriptive statistical techniques after which the results were presented in tables supported by some discussions.

The study findings established that although principals encountered numerous challenges during implementing ICT in schools, they appeared to have positive attitudes towards its implementation. Principals' interest; their commitment and championing implementation of ICT programs in schools positively influenced the whole process. A tailor-made in-service training should be regularly arranged for them in order to shift their theoretical interest in ICT into practice. 
Keywords: Challenges, principals, implementation, ICT, schools, Kenya

\section{Introduction}

Research suggests that implementing ICT can transform the existing school system by raising the efficiency and effectiveness of teaching and learning hence increasing students' achievement. Many studies emphasize the benefits of implementing ICT in schools. Papaioannon \& Charalambous (2011) stressed that ICT in school can motivate students, stimulate their interest, increase their self-esteem and self-confidence, increase their creativity, allow greater inter-activity, enhance their critical thinking and increase their attainments among other benefits. Additionally, Laaria, (2013) notes that ICT can enhance teacher's efficiency and enthusiasm, encourage their planning and co-operation, helps them adopt student-centered teaching strategies, reduce their workload, and improve relationship between teachers and students.

Many authors argue that school leadership plays a major role in implementation of ICT in school (Makhanu \& Kamper, 2012, Laaria, 2013). According to Laaria, (2013) the successful implementation of ICT in school greatly depends on the effectiveness of school leaders to manage change. The school leader plays a vital role in directing and managing positive actions that facilitates adoption and use of technology in their schools. Management of secondary schools needs to participate in formulating quality programs assisted by ICT in order to improve their school performance and foster creativity (Menjo \&Boit, 2012). However, despite emphasis on implementing ICT in schools for effective management, several studies establishes that many principals are either not actively participating on its implementation or have no considerable knowledge that can aid in its implementation (laaria, 2013, Makhanu \& Kamper, 2012)

Kenyan secondary school principals has numerous leadership roles, including management and organization of school curriculum, motivation and management of human resources in school, control and management of school finances, maintenance and management of school facilities including ICT infrastructure. In other words, school principals are the chief accounting officers in their schools (Laaria, 2013). By adopting and using ICT tools, principals can effectively influence their school performance through efficiently and effectively performing administrative functions bestowed on them. Today's principals are expected to have positive attitudes towards ICT and possess minimum skills that can help them cope with emerging technology changes.

As early as 1990s, some secondary schools in Kenya had acquired computers for use in day to-today activities of administration like storing students' data, typing, word processing, data processing etc. The initiative was partially due to pressure to effectively manage schools. However, there has been little emphasis on the adoption and use of ICT by school administrators. Kenyan government has put a lot of emphasis on transforming secondary 
school to be ICT compliant by year 2015. Towards this end, the government formulated sessional paper No. 1 of 2005 with emphasis to implementation of ICT in schools (GOK, 2005). Further, the government disseminated National ICT policy in 2006 with the following commitment in implementation of ICT in secondary schools:

- Promoting development of integrated e-learning curriculum to support ICT in schools

- Providing affordable ICT facilities to assist in dissemination of skills and knowledge through e-learning platform

- Promoting development of content to address educational needs of secondary schools

- Promoting establishment of a National ICT centre of excellence

- Facilitating sharing of ICT resources between schools

- Creating awareness of opportunities offered by ICT as an educational tool to education sector

- Exploiting ICT opportunities to offer Kenyan education programs for export and

- Integrating ICT infrastructure with other existing infrastructure in schools

This shows that the government has formulated necessary policies for implementation of ICT in schools. However, a study by Menjo \&Boit, (2012) reveal while implementation of ICT has been achieved by many sectors including medical services, banking, communications and transportation, penetrations in schools seems to lag behind. It was found that usage of computers in classroom was still in its early phases. The study concluded that the experiences and perceptions of school leaders and teachers played an important role in the implementation of ICT in Kenyan schools. This meant there was need to provide effective and efficient pre-service and in-service courses that could enable teachers successfully use computers in the course of teaching. A further study by Kipsoi, Chang'ach \& Sang (2012) suggested that the government should revise national plans to implement ICT as while as review both programs for teacher preparation and staff development.

In another study by Laaria, (2013) found that school leader's interest; their commitment and championing implementation of ICT programs in schools positively influenced the whole process. The study recommended incorporation of ICT curriculum and managerial skill to training of head teachers. It is with this background a study to determine the challenges principals encountered during implementation of ICT in schools was conceptualized.

Purpose of the study: The study was formulated to investigate the school principals' perceptions and attitudes towards implementation of ICT in schools with a purpose of establishing challenges that hinder effective adoption and use of ICT in management and teaching of public secondary schools.

Objectives of the study: This study was guided by three objectives;

1. To determine school principals' perceptions and attitudes towards implementation of ICT in schools

2. To establish challenges encountered by principals during implementation of ICT in schools. 
3. To establish school principals' views on how to overcome challenges encountered during implementation of ICT in schools.

Significance of the study: The findings and recommendations of this study are expected to provide a framework or process which should assist school principals in making decisions on how to implement ICT in schools. The planners and policy makers are expected to use the findings of this study as a base for revising the current ICT policy in order to overcome the challenges hindering smooth implementation of ICT in schools in Kenya. Further, findings of the study are expected to open areas for further study by other researchers and academicians, hence benefiting the whole community.

\section{The meaning of ICT implementation in schools}

Andoh, (2012) defines implementation as processes and decisions made by individuals every time they consider adopting innovation. Khan, Hassan \& Clement, (2012) describes implementation of ICT in schools as the decision made by school leaders and teachers to make use of technology as the best course of action available. Andoh, (2012) observes that the process of implementation of ICT starts with initial hearing about the technology to final adoption and using it.

Makhanu, (2010) describes ICTs as technologies that are used to create, manage, communicate and distribute information. According to Laaria, (2013) ICTs includes telephones, televisions, radios, computers, internet and audio-visual equipments. Makhanu, (2010) note that ICT is any application and device used to manage, access, create, evaluate, integrate and communicate information and knowledge. The author argues that digital technology is included in that definition. On the hand, Manduku, Kosgey, \& Sang, (2012) observed that ICT hardware includes desktop computers, CD drive, laptop, telephone (landline and mobile) electricity infrastructure, scanner, printer and projector. Khan et al, (2012) describes software as detailed instructions (programs) and data that enable hardware to perform its tasks at high speed.

According to Makhanu, (2010) ICT implementation involves use of technology as a tool to research, evaluate, plan, organize and communicate information. Menjo \& Boit, (2012) notes that implementation of ICT in schools involves the extent to which teachers use computers, multimedia projectors, overhead projectors and other technology tools in their day today activities. According to Makhanu, (2010) the extent of ICT implementation in schools is generally consistent with the level of economic development. The author argues that implementation of ICT involves actual adoption and use of ICT tools in administrative tasks and it involves using Internet technology and computers to improve the quality of teaching, learning and school management.

\section{The role of secondary school principal in implementation of ICT}

Several studies indicate that school principals play a major role in implementation of ICT in 
schools. Makhanu \& Kamper, (2012) observed that successful implementation of ICT in schools depends on principal leadership role in managing change in his/her school. The principal plays a critical role in taking positive actions that facilitates coping with technology change. Papaioannou \& Charalamous, (2011) agrees that principals' access to ICT plays a role in influencing the extent to which it can be implemented in school operations. According to Afsheri, Ghavifekr, Siraj \& Samad, (2012) implementation of ICT in schools will only be successful if principals actively supports it, provides adequate professional development, learns as well, supports other staff members in the process of change and engages stakeholders in financing its implementation. Laaria, (2013) noted that although ICT infrastructure is vital, technology leadership is even more essential for efficient implementation of technology to schools. The management of schools must involve themselves in the quality programs offered in schools, because the world today demands workforce that understands how to apply technology as a means of increasing creativity and production.

According to Makhonu, (2010) secondary school principals should lead the way by making comprehensive and concerted commitment in dealing with challenges that result to lack of effective implementation of technology in their schools. The successful implementation of ICT in schools is determined by principals who actively give timely support, encourage students, teachers and other school staff to appreciate technology implementation. They should device ways of meeting the challenges that their schools face in terms of implementation of ICTs. Principals should be innovative, competent and be focused in dealing with challenges that are encountered when implementing ICT in schools. Therefore, it can be argued that school principal behaviors are central to successful implementation of ICT.

\section{Challenges encountered during implementation of ICT in schools}

Several challenges encountered during implementation of ICT in schools have been identified by researchers. Hennessey (2010) identifies several constrains that hinder effective adoption of technology by schools in sub-Sahara Africa as financial constrains, lack of adequate ICT facilities, lack of reliable electricity and inadequate teachers ICT skills. Khan et al, (2012) also identifies content characteristics, user characteristics, and organizational capacity and technological considerations as factors influencing implementation of ICT in schools. Andoh, (2012) found that teacher-level factors, school-level factors and system-level factors determined implementation of ICT in schools. Implementation of ICT in schools is also influenced by organizational factors, teachers and leaders attitudes towards technology and other factors (Laaria, 2013; Manduku et al, 2012; Makhanu, 2010). The current study outlines some of such challenges in sub-sections that follow.

\subsection{Financial constrains}

According to Laaria (2013) the greatest challenge faced by school principals when implementing ICT in their schools is balancing educational goals and economic realities. 
Implementation of ICT require large capital investments, therefore, school principals need to make prudent decisions about what models of ICT to be implemented well maintaining economies of scale. The goal is whether implementing ICT offsets the costs incurred relative to the cost of alternatives.

Several researchers argue that lack of physical educational facilities, like classrooms and other buildings are major challenges faced by principals well making decisions on implementation of ICT. Hennessy, (2010) argue that ICT require supporting physical facilities to be in place before implementation. However, in many schools in developing countries like Kenya, there are rarely free rooms or suitable buildings in place. Principals of these schools have a challenge of constructing special ICT rooms (computer labs) which can be very costly. Further, implementation of ICT usually requires specialized furniture like computer desks which most schools in developing countries cannot afford.

According to GOK (2010), the current policy in Kenya is that it is the responsibility of parents to put up physical facilities particularly in secondary schools. In view of the persistent poverty, most of the parents are not able to place appropriate facilities to support implementation of ICT in schools. According to Kenya National Bureau of Statistics (2012), $49.1 \%$ of the rural population is absolutely poor. The schools in Arid and Semi-Arid parts of the country as well as urban slums areas are the most constrained. There are limited resources to equip schools with ICT infrastructure and this has been a barrier in the implementation of ICT in education curriculum delivery. The principals of these schools are faced with the challenge of providing finances that are required for implementation of ICT.

Makhonu, (2010) argue that other costs like duties and taxes levied on ICT products have made it impossible for poor schools in developing countries from implementing effective ICT. The author notes that other costs that the school principal has to factor in before embarking on implementation of ICT are, costs for training teachers, electricity tariffs, transportation of imported ICT infrastructure and maintenance costs of the equipments. Laaria, (2013) adds that more to this, is the licensing fees charged to education software. Nearly $90 \%$ of education software in use in Kenya requires licensing and annual renewal fee at considerable high cost.

Manduku et al (2012) supported these views that in public schools of most developing countries, lack of funding for implementation of ICT has led to over-reliance on external donor funding. There is inadequate funding by governments and this as posed a challenge to principals to convince donors to fund the programs in their schools. While there are computers in some Kenyan schools, effective use of ICT is in its infancy stage due to high cost of the technology, limited connectivity and uneven access to such facilities. The author notes that other countries like China, government has been giving great attention to implementation of ICT in its schools. The expenditure on ICT in schools should be significant and continuous. 


\section{Macrothink}

To reduce the financial constrains in implementation of ICT in schools, principals should encourage private sectors participation in providing the required facilities. The government should encourage private sectors involved in implementation of ICT through offering banks loans with low interest rates and zero rating duties and taxes for ICT infrastructures used in schools. This will encourage private sector to invest more in ICT in schools.

\subsection{Inadequate ICT infrastructure and poor maintenance}

Availability of ICT infrastructure is the first step towards adoption and use of technology in schools. However, a study by Hennessy (2010) revealed that lack of adequate facilities like hardware, software and internet limited accessibility of ICT to a large population in sub-Sahara Africa. The study found that other factors like transport networks, electricity, import duties, network configuration problems and technical faults compounded the problem. Nchunge, Sakwa \& Mwangi (2012) noted that in Kenya some schools had computers but this could be limited to one computer in the office of the school head. The author concluded that very few schools had sufficient ICT tools for teaching and learning. In schools with computers, the study found that the student-computer ratio was high and this was a challenge faced during integration of technology in teaching

Several studies done in Kenyan secondary school on implementation of ICT indicates that the main challenges faced during its implementation is the degree of disparity in infrastructure and limited access, especially telecommunications and electricity that exists between rural and urban areas (Makhonu, 2010, Manduku et al, Laaria, 2013). The principals of schools which are not connected with these facilities have a task to convince the government to avail them to their schools. Makhonu, (2010) notes that in some schools getting computers is relatively easy; keeping them working is a greater challenge. The author observes that many problems like attack by viruses, electrical spikes, heat, dust and normal wear and tear can bring activity in a developing country school lab to a screeching halt. While countries like South Korea's problems in implementation of ICT in schools revolve around issues of best usage of ICT infrastructure like selection of what should be transmitted to schools, Manduku et al (2012) notes that principals in Kenyan schools struggles with the challenges of acquiring those facilities and maintaining them.

\subsection{Lack of reliable electricity}

Electricity plays a critical role in the implementation and use of ICT in schools. It has been shown that electrical energy is intrinsically linked to environmental, economic and social dimensions of sustainable development of any country (Makhonu, 2010). The demand for electricity in schools in developing countries is likely to increase, both as a result of increase in students population and expansion of innovations. With absence of alternative power sources like solar panels, schools in developing countries will continue relying on electricity grid for sources of power. However, it remains amongst others, a growing challenge for developing countries to obtain and put in place reliable and secured electricity supplies, for accessing ICT and to work towards achieving sustainability. 
Since the introduction of rural electrification in Kenya, the government has extended electricity to many rural areas in the country. However, most schools are yet to be connected to National Electricity grid and those that are connected, often experience frequent and long electricity outages. In such schools, the idea of implementing ICT will require more financial backing from the government and donors. It is apparent that providing electricity is a major challenge to implementing ICT in schools. The principals in these schools have a challenge of considering alternative power sources or power backup sources in order to be able to implement ICT. These alternative sources of power can be used to provide power for small technologies like charging laptops and phones. Rebecca \& Marshall (2012) observed that in India, solar panels were used to power community computer terminals located in slum areas that were not connected to electricity grid.

\subsection{Inadequate ICT training for principals and teachers}

Teachers' ICT skills and access to professional development is critical to implementation of ICT in school. Research shows that when teachers view ICT programs are either satisfying their own needs or their student' need, it is likely they would implement it in schools (Hennessy, 2010). With proper training on how to implement ICT, teachers can offer crucial advice on how to implement it. However, training of teachers on adoption and use of ICT in most developing countries has not been appropriate. According to Makhonu, (2010) curricula used for training teachers in developing countries like Kenya faces challenges such as:

i) The curricula used for training, in most cases are oriented towards teaching technical aspects of the technology and ignore organizational and social aspects of ICT. This as effects of producing graduates who lack management and organization skills and are therefore insufficiently equipped to deal with the complexity of designing, analyzing and implementation of ICT in schools.

ii) Most of curricula used for training are copied from economically developed countries with few modifications, if any, to reflect the realities and individual needs of local schools. The training programs needs to reflect the prevailing conditions, capabilities of existing schools and availability of resources. Principals and teachers trained using these programs have challenges of converting what they learned during training to the local requirements of their schools.

iii) The programs used for training, in most cases do not accommodate emerging concepts such as Internet. Some of these training programs are geared towards producing individuals with specific skills which in most cases do not match with requirements of school organization or reflect technology changes. The key challenge has been failure to customize or develop education software to meet the local education requirements in teaching, learning and administration.

Another important challenge was meeting the cost of training teachers. Training in ICT requires a lot of expenses that most schools cannot meet. Most of training organized by schools means that only few teachers can be trained at a time due to costs. According to Andoh (2012) the most critical factor in adoption and use of ICT in schools is to meet the training cost of teachers who are already in the profession. It appears training teachers who are already practicing means additional cost to school. In a related study, Jimoyiannis \& 
Komis, (2007) found that time it took to learn to use the new technology was the biggest concern by teachers. In addition to time for training, teachers needed time to experiment with ICT tools. Given that many teachers train through in-service courses offered during school holidays, there was insufficient time for experimenting.

\subsection{Lack of enough technical support}

Technical support is vital in maintaining confidence of teachers and principals in reliability of access to ICT software and other equipments (Makhonu, 2010). Lau \& Sim, (2008) after exploring the extent of ICT adoption among secondary schools in Malaysia found that teachers perceived lack of technical support as key barrier in implementation of ICT in schools. Lack of technical support is likely to lead to teachers avoiding ICT, for concern of a technical fault occurring which they cannot rectify hence leading to lessons being unsuccessful. Principals have challenges of ensuring that their schools have well trained technical support. However, given the competitive salaries offered by other sectors in use of ICT, schools had challenges of securing competent IT technicians hence leading to some equipments not being used. Principals should find ways of ensuring that teachers have adequate access to technical support. This is essential in order to help teachers utilize fully ICT during teaching and not wasting time on fixing configurations or other technical problems.

\subsection{Negative attitudes towards ICT in schools}

Jimoyiannis \& Komis, (2007) described attitude as cultured inclination to respond in a consistently favorable and unfavorable manner with respect to a given purpose. Several studies have been conducted about teachers and principals attitudes and interest towards implementation of ICT in schools (Lau \& Sim, 2008; Jimoyiannis \& Komis, 2007). A number of these studies reveal that a considerable number of teachers hold negative attitudes towards implementation of ICT in school, portraying negative reactions to computers ranging from mild anxiety to extreme avoidance. Several attitude scales have been developed to evaluate attitudes of principals and teachers towards implementation of ICT, ranging from computer avoidance, anxiety, self-efficacy, enthusiasm, confidence, liking and usefulness of computer towards personal and social life (Manduku et al, 2012; Makhonu, 2010; Lau \& Sim 2008; Jimoyiannis \& Komis, 2007). Some of the independent variables used to evaluate attitudes of principals and teachers towards implementation of ICT are; age, gender, training, access to a computer, years of computer use and ownership of computer.

Laaria (2013) observed that school leader' positive attitudes, commitment and interest towards implementation of ICT plays significant role in overcoming various challenges that are encountered during implementation of ICT in school. The author concludes that schools with leaders who have positive expectations regarding impact of ICT in school, tends to emphasize implementation of ICT in teaching and learning than schools with leaders who have less positive attitude towards computers. Makhonu, (2010) observed that implementation of ICT can be achieved in schools if principals and teachers are fully committed in its implementation over a period of time. Principals have a challenge of changing their attitudes towards implementation of ICT. They should develop strategies that 
can sustain the technology in their school and put some effort to support other staff member implement the technology in teaching and learning by helping them understand the potential of ICT and how they can implement it into day-to-day life in the schools (Manduku et al, 2012). It is clear that principals and teachers with positive attitudes towards implementation of ICT in their school can facilitate its implementation to a great extent.

\subsection{Remedies}

Some remedial actions needs to be taken to overcome the challenges encountered during implementation of ICT in schools. Menjo \& Boit, (2012) suggest need to put procedure to ensure competent technical support is provided. The author proposes sharing of specialized IT technicians between schools within one region to avoid cost of each school hiring its own technicians. Lau \& Sim (2008) propose a teacher with ICT capabilities be chosen in each school to coordinate implementation and provide technical support to teachers.

Andoh, (2012) propose teachers to be trained on continuous basis rather than a one-off basis in order to keep upgrading their IT knowledge over time. The author argues that in-service courses should be designed that can enable all teachers to acquire ICT skills. Continued professional development of teachers is central to successful implementation of ICT in schools.

According to Bukaliya \& Mubika (2011) policies towards education should be tailor-made to improve, increase and diversify teacher training and support. The author argues that ICT should be integrated into general educational policies and be diversified to meet local needs of each school. Makhonu, (2010) observed that sensitizing stakeholders on the potential of ICT in schools is important in order to make them finance its implementation. The author suggests fund raising should be conducted to buy ICT infrastructures. Laaria (2013) noted that to a large extent principals relied on development partners and government to equip schools with ICT facilities. The author suggests, besides sensitizing stakeholders and waiting for their contributions, principals should regard ICT as priority in school and allocate enough budgets that would promote its implementation.

Conceptual framework: This study adopted a conceptual framework important in identifying challenges encountered during implementation of ICT in schools. The framework identifies the problem as lack of implementation of ICT in schools due to challenges of financial constrains, inadequate infrastructure, poor maintenance of infrastructure, unreliable electricity supply, inadequate training of staff, inadequate technical support, and negative attitude towards ICT. Remedies are indentified as fundraising and sensitizing stakeholders, provision of adequate infrastructure, connecting schools to national electricity grid, training of staff, employment of IT technicians and in service principals and teachers. Impacts are identified as improved school performance, improved competences and practical ICT skills, improved teaching methods and increased ICT application areas in schools. 


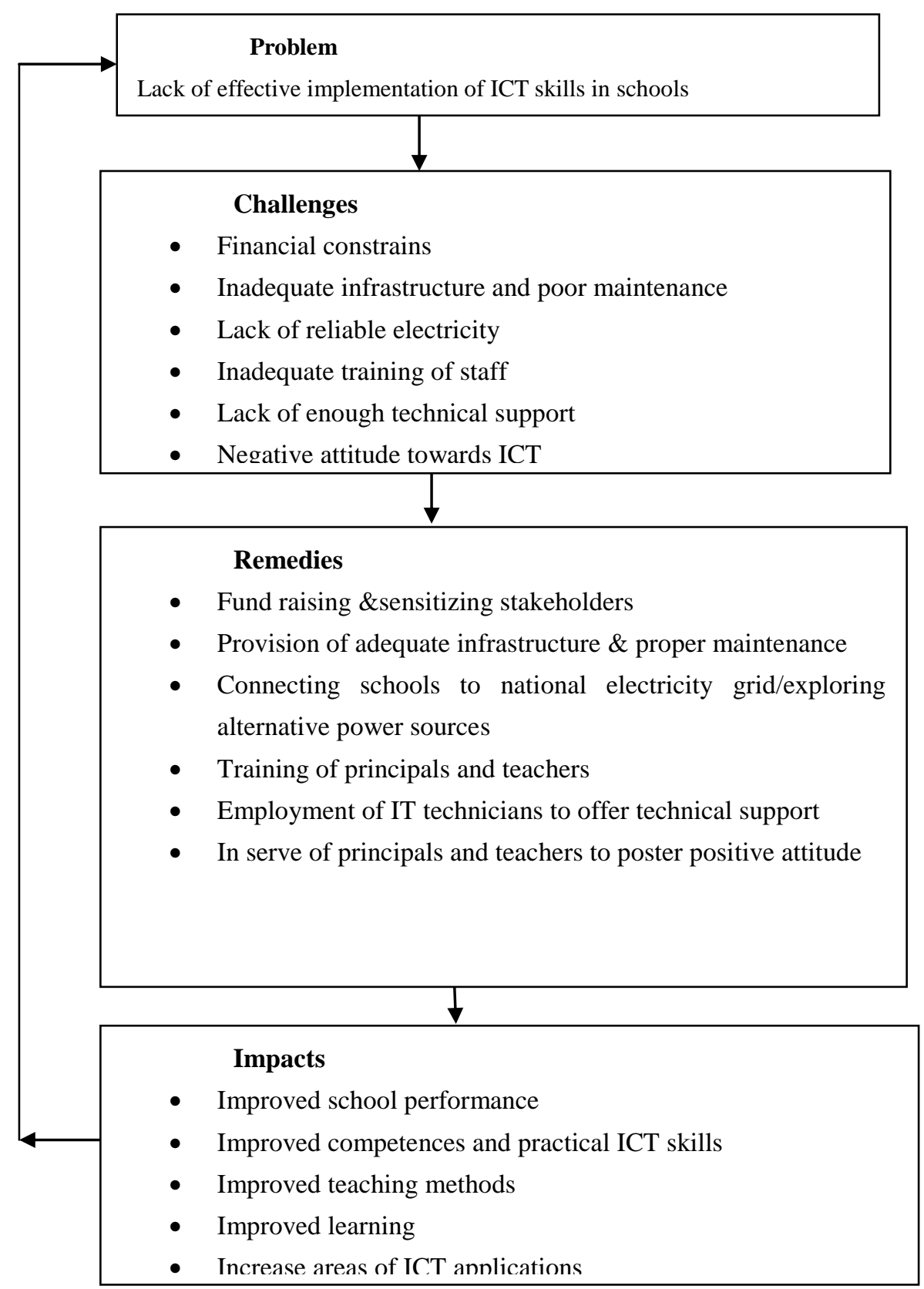

Figure1. Conceptual framework of ICT implementation in schools

\section{Methodology of study}

The study focused on investigating the challenges that were encountered by principals during implementation of ICT in schools. The study was carried out in 2012-2013 academic year in public secondary schools in Meru County. The county is situated in the Eastern province of 


\section{Macrothink}

Kenya. The focus on this County was for convenience sake, but was nevertheless valid, due to its representativeness of secondary school situation in semi-rural and rural setting in the republic. A descriptive survey research design was adopted optimizing on the strengths of a mix of qualitative and quantitative research methodologies. The target population involved all public secondary schools in the County (350) which comprised boarding schools (143) and day schools (207). Principals in these schools formed the respondents of the study. In Kenya, secondary school principals are the chief accounting officers and therefore, are suited to explain the challenges their schools encountered during implementation of ICT. A sample of $105(30 \%)$ was selected using stratified and simple random sampling. The strata of this study were boarding schools (43) and day schools (62). It should be clarified that making comparison among schools was not a primary goal of this study. Stratified random sampling method was used to select schools into strata and then simple random sampling was used to select respondents within each stratum. The reason for using stratified random sampling was to obtain a more representative sample of schools, given that there were more day schools than boarding schools and that boarding schools had considerable better educational facilities, it was imperative to use stratified random sampling to achieve more precise results.

The main instrument for data collection was questionnaires which contained both closed and open ended questions. Ninety (90) questionnaires were appropriately completed and returned for data analysis (response rate 85.71\%). A panel of expert established face and content validity of these questionnaires. Reliability was ensured through piloting in two schools which did not form part of the study. The ethical acceptability of the study was assured through a research permit issued by Ministry of Education and Meru County director of Education. Written background on the research aims and assurance of confidentiality was provided to respondents.

\section{Findings and discussions}

The findings of the study are presented in tables according to specific themes. Discussions of the data collected as well as making references to pertinent studies in the literature are also given.

\subsection{Demographics of respondents}

The respondents of the study included both males 60 (66.67\%) and females $30(33.33 \%)$. These findings revealed that there were more male principals than female principals in public secondary schools in Meru County. Most of them were degree holders. As shown in table 1, respondents were above 30 year of age and had teaching experience of aver 5 years. 
Table1. Demographics of respondents

Variable Category No. $\%$

Gender

Male

$60 \quad 66.67$

Females

$30 \quad 33.33$

Age in years

$$
31-40
$$

$15 \quad 16.67$

$$
\text { 41-50 }
$$

$37 \quad 41.11$

Over 50

$38 \quad 42.22$

Highest academic qualification
Diploma
6471.11
$17 \quad 18.89$

$9 \quad 10.00$

Degree

\begin{tabular}{|c|c|c|}
\hline Teaching experience & $5-10$ & 7 \\
\hline $11-15$ & 19 & 21.11 \\
\hline $16-20$ & 23 & 25.56 \\
\hline $21-25$ & 26 & 28.89 \\
\hline Over 25 & 15 & 16.66 \\
\hline
\end{tabular}

Master

Note: $\mathrm{No}=90$

6.2 Principals'perceptions of the implementation of ICT in schools

According to Makhanu, (2010) several factors are associated with school principals' perceptions and attitudes towards implementation of ICT in school. To evaluate the perceptions of school principals towards implementation of ICT in schools, a 15 item with five point Likert-type scale ranging from (1) strongly disagree to (5) strongly agree was administered to respondents.

Table2. Descriptive Statistics of Principals' perceptions of the implementation of ICT in schools

Variable

SD D N A SA Mean StDev $(\%)(\%)(\%)(\%)(\%)$

1. Implementation of ICT in school management

2.22

4.44

$\begin{array}{lll}15.56 & 25.56 & 52.22\end{array}$ $36.45 \quad 5.71$

will improve the operations in schools

2. ICT tools are useful in teaching and learning of $\begin{array}{lllll}6.67 & 8.89 & 14.44 & 55.56 & 14.44\end{array}$ $36.27 \quad 5.19$

almost all subject areas in the curriculum
3. ICT can improve education
$1.1112 .22 \quad 7.78$
22.22
56.67
39.16
6.38

4. Working with ICT can be enjoyable
16.6
$14.44 \quad 3.33$
$45.56 \quad 20.00$

\section{$29.73 \quad 3.84$}

and stimulating

5. ICT can put more work on the shoulders of $\quad \begin{array}{lllll}26.37 & 34.07 & 10.99 & 20.88 & 7.69\end{array}$ 
$24.72 \quad 1.73$

school principals

$\begin{array}{lllllll}\text { 6. ICT tools are difficult to use } & 18.89 & 36.67 & 6.67 & 25.56 & 12.22 & 25.48\end{array}$ 2.36

7. Capable principals do not need ICT to operate their $23.33 \quad 35.56 \quad 5.56 \quad 21.11 \quad 14.44$ $24.94 \quad 2.32$

schools efficiently

8. Implementation of ICT in school can relieve $\quad 41.11 \quad 26.67 \quad 10.00 \quad 14.44 \quad 7.78$ $27.70 \quad 2.68$

teachers of routine duties

9. ICT is useful for school management and teachers $\begin{array}{llll}18.89 & 38.89 & 8.89 & 17.78\end{array}$

$\begin{array}{lll}15.56 & 25.06 & 2.42\end{array}$

work preparation (exams, registers, typesetting, etc) only

10. Use of ICT in school would improve students' $\begin{array}{lllll}3.33 & 7.78 & 18.89 & 32.22 & 37.78\end{array}$ $28.94 \quad 3.80$

critical thinking

11. ICT in school can enhance remedial instruction $\begin{array}{lllll}6.67 & 10.00 & 12.22 & 28.89 & 42.22\end{array}$ 29.113 .78

12. Knowledge of how to use ICT tools by $\quad \begin{array}{lllll}0.00 & 4.44 & 3.33 & 53.33 & 38.81\end{array}$ $43.88 \quad 7.60$

teachers and students is worthwhile skill

13. Use of ICT cannot contribute to learning $\quad \begin{array}{lllll}34.44 & 46.67 & 2.22 & 13.33 & 3.33\end{array}$

$35.58 \quad 4.36$

because it does not stimulate students

14. Implementation of ICT can create jobs $\quad \begin{array}{lllll}13.33 & 14.44 & 16.67 & 41.11 & 14.44\end{array}$

$25.63 \quad 2.53$

than they eliminate in school

15. Use of ICT tools in school could reduce $\quad \begin{array}{lllll}27.78 & 51.11 & 7.78 & 8.89 & 4.44\end{array}$

$35.43 \quad 4.41$

personal treatment of students

Key: $\mathrm{SD}=$ Strongly

disagree $\mathrm{D}=$ Disagree $\quad \mathrm{N}=$ No opinion $\mathrm{A}=$ Agree $\mathrm{SA}=$ Strongly agree

As shown in table 2, majority of respondents' perceived implementation of ICT in schools will improve school managements operations $(77.78 \%$, mean $=36.45)$ and also ICT tools are useful in teaching and learning of almost all subjects areas in the curriculum $(70.00 \%$ mean $=$ 36.27). The majority of principals also agreed or strongly agreed that ICT can improve education $(78.89 \%$ mean $=39.16)$ and working with ICT can be enjoyable and stimulating $(65.56 \%$ mean $=29.73)$. These findings were consistence with the finding of a study done by Andoh, (2012) that concluded adoption and use of ICT improved management of schools as well enhancing performance of students. Majority of respondents disagreed or strongly disagreed with an assertion that ICT can put more work on the shoulders of school principals $(65.56 \%$ mean $=24.72)$, ICT tools are difficult to use $(55.56 \%$ mean $=25.48)$ and capable principals do not need ICT to operate their schools effectively $(58.89 \%$ mean $=24.94)$. 
Further, the principals strongly disagreed or disagreed with the statement that implementation of ICT in school can relieve teachers of routine duties $(67.78 \%$ mean $=27.70)$ and ICT is useful for school management and teachers work preparation (exams, registers, typesetting, etc) only $(57.78 \%$ mean $=25.06)$. The results are in agreement with Makhanu \& Kamper, (2012) who found that use of ICT tools helped teachers execute their duties effectively and used them for enhancing classroom teaching. The principals further agreed or strongly agreed use of ICT in school would improve students' critical thinking $(70 \%$ mean $=28.94)$ and a record, $70 \%$ (mean $=43.88)$ perceived knowledge of how to use ICT tools by teachers and students is worthwhile skill. In short, principals' perceptions of implementation of ICT in schools were positive. The findings of this study are in agreement with the results of Manduku et al, (2012) which assessed the teachers' perception towards integration of ICT in education and found that Kenyan teachers held very positive perception towards implementation of ICT. Similar positive perception towards computer use, as a tool for teaching and learning in schools, were found in a study carried out by Jimoyiannis \& Komis, (2007) in 2006-2007 amongst Kenyan secondary school educators (including principals). It is believed that principals can see the value of the ICT in their school and they actively support its implementation.

\subsection{The extend of ICT implementation in schools}

Respondents were asked to indicate to which extend ICT tools (computers, printers, overhead projectors, internet, etc) were used in their schools either on a daily and/or weekly basis. Table 2 shows that majority $71(78.88 \%)$ indicated their schools used ICT tools to average extend, less extend or not at all.

Table3. Extend of ICT implementation in schools

\begin{tabular}{|c|c|c|}
\hline \multicolumn{3}{|c|}{$\begin{array}{lll}\text { Extent } & \mathrm{No} . & \%\end{array}$} \\
\hline To a great extend & 5 & 5.56 \\
\hline To some extend & 14 & 15.56 \\
\hline Average extend & 27 & 30.00 \\
\hline To a less extend & 31 & 34.44 \\
\hline Not at all & & \\
\hline
\end{tabular}

Note: No $=90$

This data suggest that though principals' perceptions of implementation of ICT in schools were positive (as indicated in table 2) the technology was not adequately being implemented in schools. A test of relationship between perception of ICT implementation in schools and extend of ICT usage shows a weak positive linear relationship $\left(r=2.43, r^{2}=5.90, \alpha=0.09\right.$ and $\beta=2.43$ ) with a linear regression model: Extend of ICT usage in school $=0.09+2.43$ perception of ICT implementation in school. It can be argued that this relationship is weak because only $10.31 \%$ of extend of ICT usage can be attributed to perception of ICT implementation in school. This implies that perception of ICT implementation in school does not automatically result to great extend of use. Other challenges that might have hindered smooth implementation of ICT in schools should be identified and remedies to overcome them explored in order to annex the opportunities offered by ICT in schools. 
6.4 Challenges encountered during implementation of ICT in schools

On closed ended questions, respondents were asked to identify the challenges that were encountered during implementation of ICT in schools.

\section{Table 4. Challenges faced during implementation of ICT in schools}

Challenge No \%

$\overline{\text { Cost of ICT tools (computers, printers, overhead projectors, internet, etc) } 84} 93.33$

Inadequate infrastructure and poor maintenance

$78 \quad 86.67$

Inadequate and poorly trained teachers on use of ICT

$67 \quad 74.44$

Lack of technical support (for maintenance and repair of ICT tools) $\quad 58 \quad 64.44$

Limited access to the internet

5156.67

Negative attitudes towards computers by teachers

$42 \quad 46.67$

Limited and unreliable sources of power (electricity, generators etc)

Limited support by parents and government

$25 \quad 27.78$

As shown in table 4, majority of principals 84 (93.33\%) indicated the main challenge they encountered was the cost of ICT tools, while 78 (86.67\%) indicated inadequate infrastructure and poor maintenance as a challenge faced during implementation of ICT in schools. These findings are in agreement with Nchunge et al (2012) who found that in Kenya some schools had computers but this could be limited to one computer in the office of the school head. Similarly, the findings agreed with Makhonu, (2010) who asserted that in some schools getting computers is relatively easy; keeping them working is a greater challenge.

Lack of technical support (for maintenance and repair of ICT tools) was perceived by 58 $(64.44 \%)$ as challenge, while $51(56.6 \%)$ indicated limited access to internet and $42(46.67 \%)$ viewed negative attitudes towards computers by teachers as a setback to implementation of ICT in schools. These findings were in line with results of study conducted by lau and Sim (2008) which found that the main challenges hindering ICT adoption in education were limited knowledge on how to use ICT tools by teachers, lack of software, lack of time and lack of technical support. The findings also agreed with Manduku et al, (2012) who found that some teachers viewed use of computers in teaching resulted in waist of students' time needed in preparing for national examinations and it disrupted the traditional norms in classroom.

On open ended questions, the respondents were encouraged to state other challenges they faced during ICT implementation in schools. Most respondents were concerned with security of ICT tools in school. They indicated vandalism and theft which are common in schools due to lack of burglar proofing in most buildings as challenge they faced. One principal wrote "the school is not well-fenced and has structures that could easily be broken into". Laaria, (2013) found that due to fear that ICT tools could be damaged in the process of teaching and learning, most schools leaders put more effort to protect the machines from teachers and students, hence curtailing innovative use of the infrastructures by the school community. 
6.5 Possible remedies suggested by principals for challenges encountered during implementation of ICT in schools

Principals who responded to this study have also given some valuable insights on how to overcome challenges encountered during implementation of ICT in schools.

Table5. Possible remedies for challenges encountered during implementation of ICT

Suggested remedy $\mathrm{No}_{2} \%$

Fundraise to purchase ICT tools and other accessories

Enhanced teacher development in ICT through in-service courses

Teachers training institutions to offer proper ICT training to teacher trainees $\quad \begin{array}{ll}67 & 74.44\end{array}$

Involve relevant stakeholders in financing ICT infrastructures in schools 8594.44

ICT literacy should be made compulsory for all teachers

$46 \quad 51.11$

Creating awareness of opportunities offered by ICT in schools

$42 \quad 46.67$

Sharing of ICT infrastructure among the schools

$38 \quad 42.22$

As shown in table 5, seventy four (82.22\%) suggested fundraising to be conducted to purchase ICT tools. Enhanced teachers development in ICT was proposed by $83(92.22 \%)$ while $67(74.44 \%)$ suggested teacher training institutions to offer proper ICT training to teacher trainees and $85(94.44 \%)$ proposed involvement of stakeholders in financing the programs. These results were in agreements with findings of Bukaliya and Mubika (2011) who found that schools and teacher training institutions in Zimbabwe were equipped with ICT tools through fundraising and financing from donors. Creating awareness to the community of opportunities offered by ICT was suggested by $42(46.67 \%)$ while sharing ICT infrastructure among schools was proposed 38 (42.22\%) and $46(51.11 \%)$ suggested making ICT literacy compulsory for all teachers. Bukaliya and Mubika (2011) stated that since teachers' competence is a very trendy theme national curriculum, ICT capabilities needs to be made compulsory for school teachers. Resistance to change from some staff members is some of the challenges that principals should be prepared to tackle. One principal remarked "in order to encourage teachers see the potentials of implementing ICT in teaching and learning, I try to act as a role model in the process of implementation"

\section{Conclusions and Recommendations}

The current study was aimed at providing an assessment on the challenges encountered and possible remedies available during implementation of ICT in schools. From the study, it appears that most of principals were positive with implementation of ICT in schools; they appreciated adoption of ICT in enhancing teaching and learning. Principals' interest; their commitment and championing implementation of ICT programs in schools positively influenced the whole process. A tailor-made in-service training should be regularly arranged for them in order to shift their theoretical interest in ICT into practice. However, it appeared most of schools were not implementing the technology properly as reported by most respondents who indicated that schools used ICT tools to average/less extend or never used them. The study established there were challenges that affected smooth implementation of ICT in schools. The principals should be prepared to tackle these challenges in order to 
hasten its implementation.

ICT implementation efforts should not be sporadic. The goal of implementing ICT in school should be high in school agenda and the planning for its success should be continuous. The principal should be the motivational force who encourages his/her staff to appreciate technology in order to improve the quality of their work. In order to achieve this, principals' should make their support visible by making sure that all means that are essential for implementation of ICT in their schools are explored. They should actively consult stakeholders and teachers on the way forward. On this end, the education policy should be tailor-made to improve, diversify and increase teacher education and attempts and support should be made to build ICT into general educational policies. Government and other stakeholders should ensure access to quality infrastructure and learning resources and schools should develop an open knowledge-sharing school culture. Teachers and principals should be given opportunity and encouraged to reflect on, and make decisions about their own ICT progress requirements on ongoing basis. In short, it can be concluded that, although principals faced numerous challenges during implementation of ICT in schools, they appeared to have positive attitudes towards the whole process.

\section{References}

Afsheri, M, Ghavifekr, S, Siraji, S \& Samad, R (2012) Transformational leadership role of principals in implementing Information and Communication Technologies in schools, Life Science Journal 9(1) 281-284

Andoh, B. (2012) An exploration of teachers' skills, perceptions and practices of ICT in teaching and learning in the Ghanaian second-cycle schools, Contemporary Educational Technology 3(1), 36-49

Bukaliya, R. \& Mubika, A (2011) Teacher competence in ICT: implications for computer education in Zimbabwean secondary schools, International Journal of Social Sciences and Education 1(4) 414-425

Lau, B. \& Sim, C. (2008) Exploring the extent of ICT adoption among secondary school teachers in Malaysia, International Journal of Computing and ICT research 2(2) 19-36 http://www.ijcir.org/volume2- number2/article 3.pdf.

GOK, (2010) ICT Capacities and Capabilities in Secondary Schools in Kenya 2009/2010, NCST No: 046, Nairobi Kenya

GOK (2005) Session Paper No.1 of 2005 on a policy Framework for Education, Training and Research; Government printer, Nairobi Kenya

Hennessy, S. (2010) Developing the use of Information and Communication Technology to enhance teaching and learning in East African schools: Review of the Literature Aga Khan University Nairobi Kenya

Jimoyiannis, A. \& Komis, V. (2007) Examining teachers' beliefs about ICT in education: implications of a teacher preparation program, Teacher Development, An international journal of teachers' professional development, $11(2)$

149-173 http://dx.doi.org/10.1080/13664530701414779 


\section{Macrothink}

Journal of Sociological Research

ISSN 1948-5468

2013, Vol. 4, No.2

Kahn, H. Hasan, M. \& Clement, K. (2012) Barriers to the introduction of ICT into education in developing countries: the example of Bangladesh International Journal of Instruction, 5 (2) 61-80

Kenya National Bureau of statistics (2012) Strategic plan 2008-2012, Government printer, Nairobi Kenya

Kipsoi, E. Chang'ach, J \& Sang, H (2012) Challenges facing adoption of ICT in education management in schools in Kenya, Journal of sociological Research 3(1) 18-28 http://dx.doi.org/10.5296/jsr.v3i1.1882

Laaria, M. (2013) Leadership challenges in the implementation of ICT in public secondary schools, Kenya, Journal of Education and Learning 2 (1) 32-43 http://dx.doi.org/10.5539/jel.v2n1p32

Makhanu, E (2010) Principals' literacy in ICT: towards improving secondary school performance in Kenya. $\mathrm{PhD}$ thesis, University of South Africa

Manduku, J. Kosgey, A. \& Sang, H. (2012) Adoption and use of ICT in enhancing management of public secondary schools: A survey of Kesses zone secondary schools in Wareng District of Wasin Gishu County, Kenya

Menjo, D \& Boit, J (2012) The challenges of using ICT in school administration in Kenya, Moi University, Kenya PMid: 22770986

Ncunge, D. Sakwa, M \& Mwangi, W (2012) User's perception on ICT adoption for education support in schools: A survey of secondary school teacher's in Thika District Kenya, International Journal of Humanities and Social Science 2(10) 17-29

Papoioannon, P \& Charalambous, K (2011) Principals' attitudes towards ICT and their perceptions about the factors that facilitate or inhibit ICT integration in primary schools of Cyprus, journal of Information Technology $\quad$ Education 10(1) 349-369

Rebecca, W. \& Marshall, S. (2012) A new face of Education: Bring Technology into the classroom in the developing world, Global Economy and Development, Brookings

PMCid: 3303163 